\title{
Cell Surface Glycoprotein MUC18
}

National Cancer Institute

\section{Source}

National Cancer Institute. Cell Surface Glycoprotein MUC18. NCI Thesaurus. Code

C17313.

Cell surface glycoprotein MUC18 (646 aa, 72 kDa) is encoded by the human MCAM gene. This protein is involved in vascular endothelial cell adhesion. 